\title{
Knowledge, attitudes and practices of cervical cancer prevention
}

Wiedza, postawy i praktyka w profilaktyce raka szyjki macicy

\author{
Andrea Obročníková, L’udmila Majerníková
}

Department of Nursing, Faculty of Health Care, University of Prešov, Slovakia

CORRESPONDING AUTHOR/AUTOR DO KORESPONDENCJ:

Andrea Obročníková

Faculty of Health Care in Prešov, University of Prešov

ul. Partizánska 1, 08001 Prešov, Slovak Republic

tel. +421517562460

e-mail: andrea.obrocnikova@unipo.sk

\section{STRESZCZENIE}

Słowa kluczowe:

ABSTRACT

Key words:

\section{WIEDZA, POSTAWY I PRAKTYKA W PROFILAKIYCE RAKA SZYJKI MACICY}

Wprowadzenie. Rak szyjki macicy jest najbardziej powszechnym nowotworem narządów płciowych oraz jednym z wiodących przyczyn zgonów wśród kobiet w Słowacji. Obecnie tak umiejscowionemu nowotworowi można zapobiec jeśli kobiety regularnie poddają się badaniom przesiewowym w kierunku raka szyjki macicy. Wiedza kobiet dotycząca tego rodzaju badań, ich postawa oraz praktyczne uczestnictwo zostały poddane ocenie.

Materiał i metody. Badanie przekrojowe pomogło w dokonaniu ewaluacji wiedzy, postaw i praktyki dotyczących profilaktyki raka szyjki macicy oraz badania przesiewowego służącego jego wczesnemu wykrywaniu. Próbie poddano 239 kobiet między 18 a 64 rokiem życia. Dane uzyskano dzięki przeprowadzeniu kwestionariusza w okresie od stycznia do kwietnie 2015 roku.

Wyniki. Uczestniczki badania wykazały się przeciętną wiedzą dotyczącą raka szyjki macicy, czynników ryzyka oraz wczesnych objawów choroby, jednak ich świadomość odnośnie badań przesiewowych była zadawalająca. Pomimo faktu, iż osoby uczestniczące w badaniu wyrażały właściwe nastawienie do takich badań, poziom faktycznego w nich uczestnictwa był niski (64\% uczestniczyło w ginekologicznych wizytach kontrolnych, 43\% poddawało się badaniu cytologicznemu w przeciągu roku a 44\% w przeciągu trzech lat). W niniejszym badaniu zaobserwowano lepsze rezultaty u kobiet z wyższym wykształceniem jeśli chodzi o chorobę $(\mathrm{p}<.001)$. profilaktykę ( $p$ <.001) oraz zachowanie grożące ryzykiem.

Wnioski. Świadomość kobiet w Słowacji dotycząca raka szyjki macicy jest ograniczona. W związku z tym widoczna jest potrzeba propagowania i promowania takiej świadomości wśród kobiet aby zredukować zachorowalność i umieralność na tę chorobę.

rak szyjki macicy, badanie przesiewowe, profilaktyka, opieka nad chorym

\section{KNOWLEDGE, ATTITUDES AND PRACTICES OF CERVICAL CANCER PREVENTION}

Aim. Cervical cancer is the most common genital malignancy and one of the leading causes of death among female population in Slovakia. At present, this location of cancer is preventable disease visible in screening for premalignant lesions if the women use and participate in such screening regularly. We assessed the knowledge on the cervical cancer screening, the attitude towards it and its utilization among women in Slovakia.

Material and methods. A cross-sectional study evaluated the knowledge, attitude and practice of cervical cancer prevention and screening among women. The sample was composed of 239 women aged 18-64 years. Data collection was conducted by selfadministered questionnaire in a period from January to April 2015.

Results. Respondents exhibited an average knowledge of cervical cancer, about risk factors and early signs, but awareness of cervical cancer screening was satisfactory. Despite the fact that respondents expressed good attitude to cervical cancer screening, their level of practice was low (64\% participation in preventative gynaecology check-ups and $43 \%$ in Pap smear tests within one year and $44 \%$ within three years). In the study we could observe better results in women with higher education when it comes to an illness $(\mathrm{p}<.001)$, its prevention $(\mathrm{p}<.001)$ and risk behaviour $(\mathrm{p}<.001)$.

Conclusions. The awareness of cervical cancer among women in Slovakia is limited. In the future there is a need to educate and promote awareness of cervical cancer among women to reduce the burden of morbidity and mortality.

cervical cancer, screening, prevention, nursing 


\section{INTRODUCTION}

Cervical cancer is one of the leading causes of morbidity and mortality amongst the gynaecological cancers worldwide. The highest incidence of the disease has been repeatedly recorded in the less developed countries, such as Mozambique (75.9/1000 000) and other countries of central and eastern Africa. Conversely, the lowest incidence of the disease is in western Asia, than in Europe, for example in Switzerland. About half million of new cases are seen worldwide each year, most occurring in developing countries and as many as 274,000 deaths are associated with cervical cancer [1]. In Slovakia it is the second most common disease among women after breast cancer. In the National Cancer Registry of Slovakia, we annually register $600-620$ new cases and $200-220$ deaths [2]. It is diagnosed predominately in women aged $35-45$ years [3] At present we know that cervical cancer has positive association with infection of human papillomavirus (HPV), and repeated or persistent HPV infections increase the risk of developing the disease. Primary prevention strategies for HPV infection and cervical cancer are effective prophylactic HPV vaccines which only protect against $70 \%$ of the disease and are only effective for those not yet exposed to the virus. Besides that, several factors contribute to the high burden of disease such as tobacco smoking, long-term use of hormonal contraceptives, promiscuity, Chlamydia trachomatis infection, herpes simplex virus type 2, HIV, immunosuppression, certain dietary deficiencies, but also poor knowledge, lack of participation in cervical cancer screenings significantly affect the attitude of women towards their own health [4].

The screening method of the conventional cervical cytology is a secondary prevention strategy for cervical cancer which allows an early detection and treatment of cervical precancerous lesions. Smears are taken by gynaecologists and evaluated by approved cytology laboratories in Slovakia. Target population are women aged $23-64$ years. The screening intervals are $1-1-3$ years. During the first two years, the screening is cytology taken annually. Screening interval is prolonged to 3 years if the two consecutive cytological findings were negative. The screening is discontinued in women aged 64 years, whose last 3 consecutive smears were negative $[5,6]$. Practice in many countries of Europe confirmed that organized cytological cervical cancer screening can reduce the incidence of this serious disease by $80 \%$. However, such an efficiency can be achieved by inviting the target population, ensuring high participation in the screening, which can reassure the professional public's and especially target population' permanent awareness. Obviously, the epidemic of cervical cancer can be reduced with the proper awareness and practice of cervical cancer prevention measures.

\section{AIM}

The present study was carried out to assess the knowledge, attitude and practice of cervical cancer prevention measures among women in Slovakia.

\section{MATERIAL AND METHODS}

A quantitative, cross-sectional descriptive design was used. The questionnaire-based study was conducted from January to April 2015. Data was collected personally at the respective outpatient clinics in Slovakia (Banská Bystrica, Vranov nad Toplou, Košice) with prior consent from gynaecologist and respondents. In the waiting room of outpatient clinics, the nature and purpose of survey were being explained to women. Respondents who agreed to participate received a self-administered questionnaires with closed questions. The questionnaire consisted of 23 various items including demographic indicators, basic facts about cervical cancer and screening, women's access to gynaecological care, identification of risk behaviour in relation to the oncogenesis of cervical cancer. The processing of questionnaires was based on the current knowledge in the field of cervical cancer research, from the legislation applicable in the Slovak Republic and scientific review articles relating to the issue. The questionnaires were distributed to 265 respondents, but 239 were fully completed and therefore analysed. A total of 239 respondents were aged 23-64 years. The data was entered into MS Excel and analysed using SPSS (version 15.0.) computer software. In the analysis, some appropriate frequencies were generated and descriptive results were presented by using absolute frequency (n), relative multiplicity (\%). We used the nonparametric Spearman correlation coefficient to determine relations between variables.

\section{RESULTS}

The results were summarised in the tables. The survey sample consisted of 239 women. The women varied in age from 23 to 64 years, while the largest group consisted of respondents aged 23 - 40 years (70\%). Respondents achieved largely secondary (54\%) and tertiary education (41\%). Most of the respondents were married - 52\% and $34 \%$ were single.

Tab. 1. Distribution of respondents by age, educational status, marital status.

\begin{tabular}{|l|c|c|}
\hline \multicolumn{1}{|c|}{ Age } & frequency & $\%$ \\
\hline $23-30$ & 78 & $33 \%$ \\
\hline $31-40$ & 88 & $37 \%$ \\
\hline $41-50$ & 53 & $22 \%$ \\
\hline $51-64$ & 20 & $8 \%$ \\
\hline \multicolumn{1}{|c|}{ Educational status } & frequency & $\%$ \\
\hline primary & 11 & $5 \%$ \\
\hline secondary & 129 & $54 \%$ \\
\hline tertiary & 99 & $41 \%$ \\
\hline & frequency & $\%$ \\
\hline single & 80 & $34 \%$ \\
\hline married & 125 & $52 \%$ \\
\hline divorced/separated & 24 & $10 \%$ \\
\hline widowed & 10 & $4 \%$ \\
\hline
\end{tabular}


Tab. 2. Sources of information about cervical cancer.

\begin{tabular}{|l|c|c|}
\hline \multicolumn{1}{|c|}{ Sources of information } & n & $\%$ \\
\hline gynaecologist & 101 & $42 \%$ \\
\hline nurse & 16 & $7 \%$ \\
\hline leaflets, brochures & 66 & $28 \%$ \\
\hline friend & 37 & $15 \%$ \\
\hline media (TV, radio) & 115 & $48 \%$ \\
\hline Internet & 122 & $51 \%$ \\
\hline not interested in getting information & 10 & $4 \%$ \\
\hline
\end{tabular}

The most popular source of information on cervical cancer are the Internet, media and gynaecologist.

- Tab. 3. Knowledge about preventability of cervical cancer and its preventive procedures.

\begin{tabular}{|l|c|c|}
\hline \multicolumn{1}{|c|}{ Preventability of cervical cancer } & $\mathbf{n}$ & $\%$ \\
\hline it is preventable & 200 & $84 \%$ \\
\hline it isn't preventable & 15 & $6 \%$ \\
\hline don't know & 24 & $10 \%$ \\
\hline \multicolumn{1}{|c|}{ Preventive procedures } & $\mathbf{n}$ & $\%$ \\
\hline preventive gynaecological examination & 215 & $90 \%$ \\
\hline HPV vaccination & 78 & $33 \%$ \\
\hline Pap smear (cytology test) & 198 & $83 \%$ \\
\hline Suitable time for HPV vaccination & $\mathbf{n}$ & $\%$ \\
\hline before the first sexual intercourse & 144 & $60 \%$ \\
\hline after the sexual intercourse & 7 & $3 \%$ \\
\hline after the age of 18 & 37 & $16 \%$ \\
\hline don't know & 51 & $21 \%$ \\
\hline
\end{tabular}

Most respondents (84\%) considered cervical cancer as a preventable disease. The high number of women considered the preventive procedures as the preventive gynaecological examination (90\%), and Pap smear (83\%). Suitable time for HPV vaccination is, according to $60 \%$ of respondents, before the first sexual intercourse.

Tab. 4. Knowledge of cervical cancer.

\begin{tabular}{|l|c|c|}
\hline \multicolumn{1}{|c|}{ Risk factors } & $\mathbf{n}$ & $\%$ \\
\hline smoking & 94 & $23 \%$ \\
\hline immunosuppression & 83 & $35 \%$ \\
\hline HPV infection & 150 & $63 \%$ \\
\hline alternation of sexual partners & 127 & $53 \%$ \\
\hline early onset of sexual cohabitation & 52 & $22 \%$ \\
\hline absence on cervical cytology & 47 & $20 \%$ \\
\hline high number of births & 16 & $7 \%$ \\
\hline recurrent / chronic cervix diseases & 113 & $47 \%$ \\
\hline don't know & 18 & $8 \%$ \\
\hline \multicolumn{1}{|c|}{ Early signs of cervical cancer } & $\mathbf{n}$ & $\%$ \\
\hline bleeding between menstrual periods & 102 & $43 \%$ \\
\hline vaginal discharge & 115 & $48 \%$ \\
\hline discomfortand pain during sexual intercourse & 79 & $33 \%$ \\
\hline post-coital bleeding & 63 & $26 \%$ \\
\hline don't know & 39 & $16 \%$ \\
\hline Transmission of HPV infection & $\mathbf{n}$ & $\%$ \\
\hline sexual intercourse & 171 & $72 \%$ \\
\hline with their hands & 2 & $0 \%$ \\
\hline don't know & 66 & $28 \%$ \\
\hline
\end{tabular}

Respondents considered HPV infection (63\%), alternation of sexual partners (53\%), recurrent/chronic cervix diseases (47\%) as significant risk factors of cervical cancer. Awareness of the early signs of cervical cancer was average. The most often recognized by respondents signs were vaginal discharge $(48 \%)$, bleeding between menstrual periods $(43 \%)$ and discomfort and pain during sexual intercourse $(33 \%)$. As many as $28 \%$ of respondents had no knowledge about transmission of HPV infection.

Tab. 5. Participation in preventative gynaecologic check-ups and Pap smear test.

\begin{tabular}{|l|c|c|}
\hline Frequency of preventive check-ups & $\mathbf{n}$ & $\%$ \\
\hline once per year & 153 & $64 \%$ \\
\hline twice per year & 16 & $7 \%$ \\
\hline once per 2 years & 27 & $11 \%$ \\
\hline once per 3 years & 9 & $4 \%$ \\
\hline at persisting health difficulties & 34 & $14 \%$ \\
\hline \multicolumn{1}{|c|}{ Participation in Pap smear test } & $\mathbf{n}$ & $\%$ \\
\hline within the past year & 102 & $43 \%$ \\
\hline within 3 years & 106 & $44 \%$ \\
\hline above 4years & 9 & $4 \%$ \\
\hline never & 10 & $4 \%$ \\
\hline don't know & 12 & $5 \%$ \\
\hline
\end{tabular}

$64 \%$ of respondents participate in preventive gynaecological examination once a year, $14 \%$ of respondents visit a gynaecologist only in case of health problems. $87 \%$ of respondents undergo Pap smear test of the cervix in the legislatively specified intervals (43\% during the past year, $44 \%$ - 3 years ago).

Tab. 6. Risk behaviour of respondents (selected risks of life style).

\begin{tabular}{|l|c|c|}
\hline \multicolumn{1}{|c|}{ Risk behaviour } & n & $\%$ \\
\hline smoking & 62 & $26 \%$ \\
\hline use of hormonal contraceptives & 75 & $31 \%$ \\
\hline number of sexual partners: \\
\hline no partners & 4 & $1 \%$ \\
\hline 1-2 partners & 143 & $60 \%$ \\
\hline 3-4 partners & 52 & $22 \%$ \\
\hline 5 and more partners & 40 & $17 \%$ \\
\hline
\end{tabular}

Looking at risk behaviour, $26 \%$ of respondents smoked, $31 \%$ of respondents used oral contraceptives and $17 \%$ of women had five or more sexual partners. 
Tab. 7. Correlations between demographic factors and knowledge, attitudes and practices of cervical cancer prevention.

\begin{tabular}{|c|c|c|c|c|c|c|c|c|}
\hline & Age & $\begin{array}{l}\text { Education. } \\
\text { status }\end{array}$ & $\begin{array}{l}\text { Marital } \\
\text { status }\end{array}$ & Information & $\begin{array}{c}\text { Participation prev. } \\
\text { gynaecology }\end{array}$ & $\begin{array}{c}\text { Knowledge about } \\
\text { preventability }\end{array}$ & $\begin{array}{l}\begin{array}{l}\text { Knowledge of } \\
\text { cervical cancer }\end{array} \\
\end{array}$ & $\begin{array}{c}\text { Risk } \\
\text { behaviour }\end{array}$ \\
\hline Age & 1.0 & & & & & & & \\
\hline Educational status & 0.217 & 1.0 & & & & & & \\
\hline Marital status & -0.144 & -0.172 & 1.0 & & & & & \\
\hline Information & 0.351 & 0.235 & 0.276 & 1.0 & & & & \\
\hline $\begin{array}{l}\text { Participation in } \\
\text { preventative gynaecology }\end{array}$ & 0.421 & 1.0 & -0.072 & 0.321 & 1.0 & & & \\
\hline $\begin{array}{l}\text { Knowledge about } \\
\text { preventability }\end{array}$ & 0.489 & $0.893^{* * *}$ & -0.133 & 0.485 & 0.352 & 1.0 & & \\
\hline $\begin{array}{l}\text { Knowledge of cervical } \\
\text { cancer }\end{array}$ & 0.378 & $0.895^{* * *}$ & -0.139 & 0.012 & 0.214 & 0.114 & 1.0 & \\
\hline Risk behaviour & 0.258 & $0.895^{* * *}$ & -0.216 & 0.235 & 0.341 & 0.214 & 0.236 & 1.0 \\
\hline
\end{tabular}

${ }^{*} p<.05 ;{ }^{* *} p<.01 ;{ }^{* * *} p<.001$

From the perspective of correlation relationships, we have confirmed the relationship between the level of education and the knowledge about prevention, about cervical cancer and risk factors $(\mathrm{p}<.001)$. In terms of other demographic data (age and marital status), we did not confirm the dependence between the observed variables.

\section{DISCUSSION}

According to the latest scientific findings, it is obvious that cervical cancer is a preventable disease of public health. An invasive cervical cancer is the second most common cancer in women worldwide, but we try to protect them against it by adherence to preventive measures. For the correct protection against cervical cancer three prerequisites are important: the relevant information, the right attitude to own health, motivation to practice prevention.

The major sources of information about the cervical screening in this study were electronic media and health professionals (mostly gynaecologists).

$84 \%$ of respondent consider cervical cancer as preventable disease and perceive preventive gynaecological examination and Pap smear test as effective preventive procedures, but HPV immunization is perceived this way only by $33 \%$ respondents. According to Rob [7], the vaccination against HPV infection in women has the highest effect before the beginning of sexual life when it is proved to have $100 \%$ protection against types 16 and 18 . In some countries with long-standing organized screening a decline of disease by $80 \%$ was observed if the population of immunization against HPV infection, increased up to $94 \%$ $[8,9]$. We assume that the low rating of HPV vaccination is associated with the beginnings of HPV vaccination since 2007 in Slovakia and no experience with the vaccine as it is more suitable for young virginal girls and also because of the high price of the vaccines.

Knowledge about causes and early signs of disease amounted to less than average results. The relatively low percentage was recorded in risks such as smoking (23\%), early onset of sexual cohabitation (22\%), absence on cervical cytology (20\%) and multiparity (7\%). Among the early signs we have seen low values of discomfort and pain during sexual intercourse (33\%), post-coital bleeding (26\%). Better knowledge has been recorded in the area of prevention, disease and its risk factors in women with higher education. These adverse findings require to intensify an awareness of the disease through various means to provide relevant professional information.

Although the respondents are aware of the benefits of preventive gynaecological examination and Pap smear, most of them don't regularly participate in them. The low percentage $(64 \%)$ of the respondents have undergone preventive check-up once per 1 year and $87 \%$ Pap smear test within 3 years, while the legislative norm's periodicity of cervical cancer screening in asymptomatic women aged 23-64 years is the following frequency 1 - 1 - 3 year. 29\% of respondents neglect preventive checks in gynaecologist. In several studies, the most frequent reasons for the preventive examination neglect were lack of time and embarrassment / shame of examinations $[10,11,12]$.

Responsibility for health is part of the prevention in terms of civilization diseases. Their occurrence is conditioned mainly by lifestyle. Generally, smoking is not only active but also passive, and has a significant influence on the incidence of cervical cancer. Carcinogenic substances contained in tobacco are released and concentrated in the cervical mucus, which is responsible for long term persistence of the increase in the proliferation of cervical cells, being the combined effect of HPV infection susceptible to malignant transformation degenerative [13]. According to The International Agency for Research on Cancer [14], women who have ever smoked have an increased risk of cervical cancer, but in the smokers of 15 or more cigarettes a day, the positive finding of HPV are around twice more likely. It also describes three times higher risk of developing cervical cancer in women taking oral contraceptives for 5-9 years compared to women who have never used contraception [15]. A higher number of sexual partners predisposes a woman to more exposure to the human papilloma virus [16]. Hlavatá [17] states that in women who have never had sexual intercourse, cervical cancer never develops. The disease also occurs less frequently in women using barrier contraceptive methods. Drolet et al. [18] in their study highlighted the causal relationship between the occurrence of cervical cancer and low 
socio-economic status and alternating large number of partners. In our study, we have been more responsive in the case of college-educated women.

In the view of cervical cancer risk, we found that the respondents preferred unhealthy habits such as smoking (26\%), use of contraception $(31 \%)$, or alternation of sexual partners $(17 \%)$. In this area, it is desirable to integrate and support some information campaigns. In addition to health professionals and media, the communication with parents, girls and schools play a decisive role.

\section{CONCLUSION}

Based on the results of the study we propose the following recommendations:

- to increase public awareness of cervical cancer and to improve the attitude of women to their own health through the mass media and educational campaigns,

- to create educational materials (leaflets and posters) containing information about cervical cancer and its possible prevention prepared by care professionals, that would be placed in waiting rooms and outpatient clinics of general practitioners, gynaecologists, paediatricians, but also in the inpatient clinics/ departments,

- to distribute leaflets and brochures about the benefits of vaccination against HPV infection in primary care outpatient clinics for children and adolescents,

- for community nursing (school nurse): to organize educational seminars on the topic of cervical cancer, risk behaviour, HPV vaccination, prevention of sexually transmitted diseases,

- in cooperation with gynaecologists to invite women to preventive gynaecological examinations in regular intervals through the „invitations”,

- to explain the benefits of HPV vaccination for female population and to improve the availability of vaccines in relation to the cost of the vaccine, in collaboration with health insurance companies (financially favourable conditions for women who regularly undergo preventive gynaecological examinations).

Irreplaceable in primary and secondary prevention is just a nurse who plays the role of first contact in the outpatient clinics. The highly erudite nurse knows patients and their family members so in the case of the cancer incidence in the family, first-degree relatives should recommend screening tests (smear test and colposcopy) for prevention of cervical cancer.

\section{REFERENCES}

1. Ferlay J, Soerjomataram I, Dikshit R, et al. Cancer incidence and mortality worldwide: Sources, methods and major patterns in GLOBOCAN 2012. Int J Cancer. 2015;136(5):E 359-E386.

2. Národné centrum zdravotníckych informácií, Národný onkologický register SR. 2015, Incidencia zhubných nádorov v Slovenskej republike 2009. ed. Safaei Diba, Ch. vyd. NCZI SR, NOR SR; 2015. s. 191.

3. Ondrušová M, Sadovský 0, Pšenková M. Epidemiológia vybraných gynekologických malignít na Slovensku. Onkológia. 2015;10(4):223-225.

4. Underwood SM, Ramsay-Johnson E, Browne L, Caines N, Dean A, Duval S, et al. What women in the United States Virgin Islands still want and need to know about HPV, cervical cancer, and condom use. J Natl Black Nurses Assoc. 2010;21(1):25-32.

5. Sadovský 0. Skríning rakoviny krčka maternice na Slovensku. Onkológia. 2014;9(3):144-148.

6. Act No. 661/2007 of Code which amended the Act No. 577/2004 o rozsahu zdravotnej starostlivosti uhrádzanej na základe verejného zdravotného poistenia a 0 úhradách za služby súvisiace s poskytovaním zdravotnej starostlivosti v znení neskorších predpisov a o zmene a dopInení niektorých zákonov.

7. Rob L. Screening karcinomu děložního hrdla. Onkologická péče. 2007;11(1):12-14.

8. Zubor P, Danko J, Kajo K, et al. Low affordability may limit the effect of cervical cancer vaccination in central and eastern European countries. J Clin Oncol. 2007;25(34):5534-5537.

9. Ondrušová $\mathrm{M}$, Zubor $\mathrm{P}$, Ondruš $\mathrm{D}$. Time trends in cervical cancer epidemiology in the Slovak Republic: reflection on the non-implementation of screening with international comparisons. Neoplasma. 2012;59(2):121-128.

10. Park MJ, et al. Sociodemographic gradients in breast and cervical cancer screening in Korea: the Korean National Cancer Screening Survey (KNCSS) 2005-2009. BMC Cancer. 2011;11(257):1-8.

11. Ibekwe CM, Hoque ME, Ntuli-Ngcobo B. Perceived barriers of cervical cancer screening among women attending Mahalapye district hospital, Botswana. Archives of Clinical Microbiology. 2011;2:1-9.

12. Waller J, Bartoszek M, Marlow L, Wardle J. 2009. Barriers to cervical cancer screening attendance in England: a population-based survey. J Med Screen. 2009;16(4):199204.

13. Petruželka L, et al. Klinická onkologie. 1. vyd. Praha: Karolinum; 2003, s. 274.

14. IARC, 2013. HPV and cervical cancer curriculum. [online]. [cit. 29. October 2016]. Available from: http://screening.iarc.fr/cxcaccurriculum.php?lang=1

15. NCl, 2012. Oral contraceptives and risk cancer. [online]. [cit. 20. December 2016]. Available from: http://www.cancer.gov/cancertopics/factsheet/Risk/oralcontraceptives

16. Hensley, M. A Sexual Activity and Cervical Cancer Risk? [online]. last update 5.5 . 2008. [cit. 13. November 2016]. Available from: http://www.everydayhealth.com/ specialists/women/hensley/qa/sex-and-cervical-cancer-risk/index.aspx

17. Hlavatá L. Očkování proti rakovině děložního čípku. [online 15.7.2012]. [cit. 12. September 2016]. Available from: http://cs.medixa.org/lecba/ockovani-protirakovine-delozniho-cipku

18. Drolet $M$, et al. Sociodemographic inequalities in sexual activity and cervical cancer screening: implications for the success of human papillomavirus vaccination. Cancer Epidemiol Biomarkers Prev. 2013;22(4):641-52.

Manuscript received: 09.12.2016

Manuscript accepted: 11.03.2017

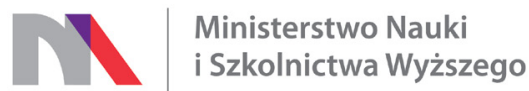

„Konsultacje z zagranicznymi naukowcami i wprowadzenie dwujęzycznych (j. polski/angielski) treści do czasopisma Pielęgniarstwo XXI wieku" finansowane w ramach umowy 547/P-DUN/2016 ze środków Ministra Nauki i Szkolnictwa Wyższego przeznaczonych na działalność upowszechniającą naukę. 